\title{
Prestasi Belajar Siswa : Kompetensi Pedagogik Guru dan Motivasi Belajar Siswa
}

\author{
Roy Wahyuningsih \\ Program Studi Pendidikan Ekonomi, STKIP PGRI Jombang \\ Corresponding Author. Email: roystkipjb@gmail.com
}

\begin{abstract}
This study aims; (1) to analyze the effect of teacher pedagogic competence on student achievement, (2) to analyze the effect of learning motivation on student achievement, (3) to analyze the effect of pedagogic competence and student motivation on student achievement. This research is a quantitative study using multiple linear regression. This study used a population study with all XI TKJ students of SMKN 1 Trowulan, totaling 60 students. Researchers used a questionnaire in the form of google form as an instrument to facilitate data collection. From the results of multiple linear regression analysis, it can be concluded that (1) pedagogical competence has an effect on student achievement; (2) learning motivation affects student achievement, (3) pedagogical competence and student motivation affect student achievement.
\end{abstract}

\begin{abstract}
Abstrak: Penelitian ini bertujuan; (1) menganalisis pengaruh kompetensi pedagogik guru terhadap prestasi belajar siswa, (2) menganalisis pengaruh motivasi belajar terhadap prestasi siswa, (3) menganalisis pengaruh kompetensi pedagogik dan motivasi belajar siswa terhadap prestasi belajar siswa. Penelitian ini merupakan penelitian kuantitatif dengan menggunakan analisis regresi liner berganda. Penelitian ini menggunakan studi populasi dengan seluruh siswa XI TKJ SMKN 1 Trowulan yang berjumlah 60 siswa. Penelitian ini menggunakan angket dalam bentuk google form sebagai instrument untuk mempermudah pengambilan data. Dari hasil uji analisis regresi linear berganda dapat ditarik kesimpulan(1) kompetensi paedagogik berpengaruh terhadap prestasi belajar siswa; (2) motivasi belajar berpengaruh terhadap prestasi siswa, (3) kompetensi pedagogik dan motivasi belajar siswa berpengaruh terhadap prestasi belajar siswa.
\end{abstract}

Article History

Received: 26-01-2021

Revised: 17-02-2021

Published: 04-04-2021

Key Words:

Student

Achievement

Pedagogic

Competence,

Learning Motivation

\section{Sejarah Artikel}

Diterima: 26-01-2021

Direvisi: 17-02-2021

Diterbitkan: 04-04-2021

How to Cite: Wahyuningsih, R. (2021). Prestasi Belajar Siswa : Kompetensi Pedagogik Guru dan Motivasi Belajar Siswa. Jurnal Paedagogy, 8(2). doi:https://doi.org/10.33394/jp.v8i2.3472

\section{Pendahuluan}

Salah satu indikator untuk menentukan usaha belajar siswa adalah melalui prestasi belajar. Jika usaha belajar siswa baik maka semakin baik prestasi belajar yang diperoleh (Inayah, 2013). Faktor intern dan faktor ekstern turut menyumbang pencapaian prestasi belajar siswa. Prestasi belajar peserta didik dapat diketahui setelah melakukan evalusai dimana hasil evaluasi tersebut memperlihatkan tentang tinggi atau rendahnya prestasi belajar siswa. (Yulianti, 2012).

Setiap mata pelajaran mempunyai tujuan pembelajaran masing-masing dan tujuan salah satunya adalah untuk meningkatkan prestasi belajar siswa. Demikian juga pada tujuan pembelajaran IPS di SMKN Trowulan Mojokerto yaitu dengan tercapainya prestasi belajar siswa yang baik yang ditandai adanya perubahan aspek kognitif, afektif dan psikomotorik. Siswa dikatakan berhasil dalam belajar jika memiliki minimal ketuntasan belajar mencapai nilai 70. Namun kenyataannya pada siswa di kelas XI TKJ SMKN 1 Trowulan Mojokerto sebanyak 20 siswa mendapat nilai kurang dari KKM yaitu minimal 70. 
Penguasaan materi ajar, pengelolaan kelas, pengeloalaan program belajar mengajar merupakan komponen penting yang terkait dengan masalah pembelajaran dan sangat mempengaruhi prestasi belajar siswa (Andriawati, 2013). Kompetensi pedagogik sebagaimana diungkapkan oleh (Yulianti, 2012) adalah kemampuan guru dalam mengelola pembelajaran siswa-siswa yang terdiri dari pemahaman peserta didik, perencanaan dan implementasi proses pembelajaran, evalusi hasil belajar dan pengembangan siswa siswa untuk mengaktualisasikan potensi-potensi yang dimiliknya.

Menurut UU RI 2005 tentang Guru dan Dosen, kompetensi guru meliputi kompetensi pedagogik, kompetensi kepribadian, kompetensi professional dan kompetensi sosial sedangkan yang dimaksud kompetensi pedagogik adalah salah satu kompetensi yang harus dikuasai oleh guru karena pada kompetensi ini merupakan kemampuan mengelola pembelajaran peserta didik yang meliputi pemahaman terhadap peserta didik, perencanaan dan pelaksanaan pembelajaran, evaluasi hasil belajar, dan pengembangan peserta didik untuk menguaktualisasikan berbagai potensi yang dimilikinya (Andriawati, 2013).

Selain kompetensi pedagogik yang dimiliki oleh guru, motivasi belajar siswa juga berperan dalam meningkatkan pencapaian prestasi siswa. Hal tersebut dikarenakan motivasi merupakan niat atau dorongan yang menggerakkan siswa untuk mau atau tidak mengikuti proses pembelajaran (Inayah, 2013). Motivasi juga dipandang sebagai dorongan untuk menggerakkan dan mengarahkan perilaku yang didalamnya termasuk perilaku pebelajar. Di dalam motivasi itulah terdapat keinginan untuk membuat aktif, menggerakkan, menyalurkan dan mengarahkan sikap serta perilaku individu pebelajar. (Hamdu \& Agustina, 2011). Motivasi berperanan penting dalam menggerakkan aktivitas belajar seseorang. (Prihartanta, 2015).

Beberapa penelitian terdahulu menemukan adanya pengaruh positif antara kompetensi pedagogik berpengaruh terhadap motivasi belajar siswa. Penelitian tersebut dilakukan oleh (Baisa \& Asmahasanah, 2020), kompetensi pedagogik berpengaruh terhadap prestasi belajar siswa (Afriyani et al., 2017), kompetensi pedagogik mempunyai hubungan positif terhadap prestasi belajar (Yulianti, 2012), (Sulfemi \& Lestari, 2017), (Ni Made Mega Setyawati, 2020). Kompetensi pedagogik dan motivasi kerja guru berpengaruh signifikan terhadap prestasi belajar siswa. (Umami \& Roesminingsih, 2014). Kompetensi pedagogik mempunyai hubungan positif terhadap prestasi belajar. (Sulfemi \& Lestari, 2017). Kompetensi pedagogik guru dan motivasi belajar siswa berpengaruh terhadap hasil belajar siswa (Novianti \& Supardi, 2018). Namun berdasarkan penelitian terdahulu yang dilakukan oleh (Inayah, 2013) mengatakan bahwa kompetensi guru berpengaruh positif secara langsung terhadap prestasi belajar siswa akan tetapi tidak berpengaruh secara langsung melalui variabel motivasi belajar siswa.

Berdasarkan latar belakang yang telah dipaparkan, maka tujuan dalam penelitian ini adalah (1) menganalisis pengaruh kompetensi pedagogic guru terhadap prestasi belajar siswa, (2) menganalisis pengaruh motivasi belajar terhadap prestasi siswa, dan (3) menganalisis pengaruh kompetensi pedagogik dan motivasi belajar siswa terhadap prestasi belajar siswa.

\section{Metode Penelitian}

Penelitian ini merupakan penelitian kuantitatif dengan jumlah populasi seluruh siswa kelas XI TKJ SMKN 1 Trowulan sebanyak 60 siswa. Populasi dipilih dikelas XI TKJ dikarenakan dikelas tersebut sudah ada penjurusan sesuai dengan minat siswa. Karena jumlah populasi kurang dari 100 maka sampel yang dipakai berjumlah 60 siswa. 
Peneliti menggunakan angket dalam bentuk google form sebagai instrument untuk mempermudah pengambilan data. Jabaran angket tersebut adalah sebagai berikut ini:

Tabel 1. Deskripsi Angket

\begin{tabular}{|c|c|c|c|}
\hline No & Variabel & Indikator & Item \\
\hline \multirow[t]{5}{*}{1} & $\begin{array}{l}\text { Kompetensi } \quad \text { Pedagogik } \\
\text { Guru }\end{array}$ & $\begin{array}{l}\text { a. kemampuan memahami wawasan atau } \\
\text { landasan kependidikan; }\end{array}$ & 1,2 \\
\hline & & b. kemampuan memahami peserta didik; & 3,4 \\
\hline & & $\begin{array}{l}\text { c. kemampuan mengembangkan } \\
\text { kurikulum/silabus; }\end{array}$ & 5,6 \\
\hline & & d. kemampuan merancang pembelajaran; & 7,8 \\
\hline & & $\begin{array}{l}\text { e. kemampuan melaksanakan pembelajaran yang } \\
\text { mendidik }\end{array}$ & 9,10 \\
\hline 2 & Motivasi Belajar & $\begin{array}{l}\text { a. Keterlibatan dan konsentrasi selama mengikuti } \\
\text { pembelajaran } \\
\text { b. Ketekunan merekam tugas terstruktur } \\
\text { c. Keinginan mendapatkan nilai yang bagus } \\
\text { d. Tekun dalam menghadapi tugas }\end{array}$ & $\begin{array}{l}11,12 \\
13,14 \\
15,16 \\
17,18\end{array}$ \\
\hline 3 & Prestasi Belajar & Nilai mata pelajarann IPS kelas XI TKJ & $\begin{array}{l}\text { Nilai } \\
\text { Ulangan } \\
\text { Harian } \\
\text { Nilai UTS }\end{array}$ \\
\hline
\end{tabular}

Peneliti melakukan uji instrument kepada 30 responden sebelum mendistribusikan angket melalui google form. Uji validitas dan reliabilitas digunakan dalam penelitian ini. Analisis penelitian ini menggunakan analisis uji regresi linear ganda dan juga pengujian hipoesis yang teridiri dari uji $\mathrm{F}$, uji $\mathrm{t}$, dan uji $\mathrm{R}^{2}$. uji normalitas, heterokedastisitas, multikolinearitas dan autokorelasi digunakan peneliti sebelum menggunakan analisis regresi berganda. Pengolahan data yang digunakan peneliti dengan bantuan program SPSS 22.00 for windows.

\section{Hasil Penelitian dan Pembahasan}

Pengujian autokorelasi digunakan untuk menguji suatu model apakah kesalahan pengganggu masing-masing variabel bebas saling berkorelasi. Data sebagaimana disajikan dalam tabel berikut:

\section{Tabel 2. Hasil Pengujian Autokorelasi}

Model Summary ${ }^{\mathrm{b}}$

\begin{tabular}{|l|l|r|r|r|r|}
\hline $\begin{array}{l}\text { Mod } \\
\mathrm{el}\end{array}$ & $\mathrm{R}$ & $\begin{array}{c}\mathrm{R} \\
\text { Square }\end{array}$ & $\begin{array}{r}\text { Adjusted } \\
\text { R Square }\end{array}$ & $\begin{array}{r}\text { Std. Error of } \\
\text { the Estimate }\end{array}$ & $\begin{array}{l}\text { Durbin- } \\
\text { Watson }\end{array}$ \\
\hline 1 & $.657^{\mathrm{a}}$ & .432 & .412 & 3.82271 & 1.780 \\
\hline
\end{tabular}

a. Predictors: (Constant), Motivasi Belajar,

Kompetensi Pedagogik Guru

b. Dependent Variable: Prestasi Belajar

Sumber: data yang diolah dari program SPSS versi 20

Dari hasil tabel di atas nampak bahwa Durbin Watson yang dihasilkan dari model regresi adalah 1.780. Sedangkan dari tabel Durbin Watson dengan signifikasi 0,05 dan jumlah data $(\mathrm{n}=60$ serta $\mathrm{k}=2),(\mathrm{k}$ adalah jumlah variabel independen) diperoleh nilai dU sebesar 1.6518, 
dan nilai $\mathrm{dU}<\mathrm{DW}<4-\mathrm{dU}$ atau nilai $1.6518<1.780<2.3482$ maka yang berarti tidak ada autokorelasi

\section{Uji Regresi Linier Berganda}

Tabel 3. Deskriptif

Descriptive Statistics

\begin{tabular}{|l|r|r|r|}
\hline & Mean & Std. Deviation & N \\
\hline Prestasi Belajar & 87.8500 & 4.98413 & 60 \\
Kompetensi Pedagogik Guru & 43.0833 & 2.99317 & 60 \\
Motivasi Belajar & 34.4333 & 2.88401 & 60 \\
\hline
\end{tabular}

Sumber: data yang diolah dari program SPSS versi 20

Hasil penelitian secara deskriptif di peroleh nilai rata-rata skor variabel Kompetensi Pedagogik Guru $(x 1)=43,0833$ rata-rata skor variabel Motivasi Belajar $(x 2)=34,4333$ dan nilai rata-rata skor variabel Prestasi Belajar $(Y)=87.8500$.

\section{Tabel 4. Persamaan Regresi}

Coefficients $^{\mathrm{a}}$

\begin{tabular}{|c|c|c|c|c|c|c|}
\hline & & \multicolumn{2}{|c|}{$\begin{array}{l}\text { Unstandardized } \\
\text { Coefficients }\end{array}$} & $\begin{array}{l}\text { Standardized } \\
\text { Coefficients } \\
\end{array}$ & \multirow[b]{2}{*}{$\mathrm{T}$} & \multirow[b]{2}{*}{ Sig. } \\
\hline \multicolumn{2}{|c|}{ Model } & $\mathrm{B}$ & Std. Error & Beta & & \\
\hline & (Constant) & 33.956 & 8.316 & & 4.083 & .000 \\
\hline & Kompetensi Pedagogik Guru & .649 & .172 & .390 & 3.766 & .000 \\
\hline & Motivasi Belajar & .753 & .179 & .435 & 4.206 & .000 \\
\hline
\end{tabular}

a. Dependent Variable: Prestasi Belajar

Dari tabel di atas, maka dapat disusun persamaan regresi linier berganda, sebagai berikut:

$$
Y=33.956+0.649 X_{1}+0.753 X_{2}
$$

Dari persamaan regresi linier berganda dapat dijelaskan sebagai berikut:

a. Konstanta (a) sebesar 33.956 : artinya apabila tidak ada variabel yang mempengaruhi atau variabel lain diasumsikan 0 (nol), maka dapat dipersepsikan bahwa tidak ada prestasi belajar sama sekali bila semua variabel bebas tidak ada.

b. Koefisien regresi variabel Kompetensi Pedagogik Guru (X1) sebesar 0.649 artinya bahwa setiap perubahan variabel Kompetensi Pedagogik Guru (X1) akan diikuti peningkatan prestasi belajar sebesar 0.649. Dalam hal ini faktor lain yang mempengaruhi prestasi belajar, dianggap konstanta (tetap).

c. Koefisien regresi variabel motivasi belajar (X2) sebesar 0.753 artinya bahwa setiap perubahan variabel motivasi belajar (X2) akan diikuti peningkatan prestasi belajar sebesar 0.753. Dalam hal ini faktor lain yang mempengaruhi prestasi belajar, dianggap konstanta (tetap). 


\section{Uji Hipotesis}

\section{a) Uji Parsial}

Tabel 5. Hasil Uji parsial (uji t)

\begin{tabular}{|c|c|c|c|c|c|c|}
\hline \multirow{3}{*}{\multicolumn{2}{|c|}{ Model }} & \multicolumn{5}{|c|}{ Coefficients $^{\mathrm{a}}$} \\
\hline & & \multicolumn{2}{|c|}{$\begin{array}{l}\text { Unstandardized } \\
\text { Coefficients }\end{array}$} & $\begin{array}{c}\text { Standardized } \\
\text { Coefficients }\end{array}$ & \multirow[b]{2}{*}{$\mathrm{T}$} & \multirow[b]{2}{*}{ Sig. } \\
\hline & & B & Std. Error & Beta & & \\
\hline 1 & (Constant) & 33.956 & 8.316 & & 4.083 & .000 \\
\hline & $\begin{array}{l}\text { Kompetensi Pedagogik } \\
\text { Guru }\end{array}$ & .649 & .172 & .390 & 3.766 & .00 \\
\hline & Motivasi Belajar & .753 & .179 & .435 & 4.206 & .000 \\
\hline
\end{tabular}

a. Dependent Variable: Prestasi Belajar

Sumber: data yang diolah dari program SPSS versi 20

Dari tabel diatas diketahui masing-masing variabel adalah sebagai berikut:

1) Koefisien variabel Kompetensi Pedagogik Guru (X1), uji t dibandingkan dengan kolom sig pada tabel 0,000. Berdasarkan out put SPSS versi 18, tabel Coefficients, pada kolom sig dan $\mathrm{t}$ dipakai untuk menguji koefisien uji $\mathrm{t}$ secara parsial. Terlihat pada $\mathrm{p}$-value (kolom Sig) = 0,000 yang lebih kecil dari 0,05 artinya ada pengaruh secara parsial Kompetensi Pedagogik Guru terhadap prestasi belajar.

2) Koefisien variabel motivasi belajar (X2), uji t dibandingkan dengan kolom sig pada tabel 0,000. Berdasarkan out put SPSS versi 20.00, tabel Coefficients, pada kolom sig dan $t$ dipakai untuk menguji koefisien uji t secara parsial. Terlihat pada p-value (kolom Sig $)=0,000$ yang lebih kecil dari 0,05 artinya ada pengaruh secara parsial motivasi belajar terhadap prestasi belajar.

\section{Uji Simultan}

\section{Tabel 6. Hasil Uji Simultan (uji F)}

ANOVA $^{\mathrm{b}}$

\begin{tabular}{|ll|r|r|r|c|c|}
\hline \multicolumn{1}{|l|}{ Model } & Sum of Squares & Df & Mean Square & F & Sig. \\
\hline 1 & Regression & 632.702 & 2 & 316.351 & 21.648 & $.000^{\mathrm{a}}$ \\
& Residual & 832.948 & 57 & 14.613 & & \\
Total & 1465.650 & 59 & & & \\
\hline
\end{tabular}

a. Predictors: (Constant), Motivasi Belajar, Kompetensi Pedagogik Guru

b. Dependent Variable: Prestasi Belajar

Sumber: data yang diolah dari program SPSS versi 20

Pengujian hipotesis secara keseluruhan yang dilakukan dengan Uji F, ditunjukkan sesuai pada lampiran anova kolom $F$, didapat nilai $F$ hitung sebesar 21.648, dengan $\alpha=(0,05)$ $\mathrm{df}=\mathrm{n}-\mathrm{k}-1=60-2-1=57$ sehingga $\mathrm{F}$ tabel $=3,16$, nilai ini menunjukkan bahwa nilai $\mathrm{F}$ hitung > F tabel, ini berarti ada pengaruh secara simultan variabel Kompetensi Pedagogik Guru (X1), motivasi belajar (X2) terhadap prestasi belajar (Y). 


\section{Tabel 7. Hasil Uji Determinasi $\left(\mathbf{R}^{2}\right)$}

\begin{tabular}{|r|r|r|r|r|r|r|r|r|r|r|}
\hline & & & & & \multicolumn{3}{|c|}{ Change Statistics } \\
Model & $\mathrm{R}$ & R Square & $\begin{array}{c}\text { Adjusted R } \\
\text { Square }\end{array}$ & $\begin{array}{c}\text { Std. Error of } \\
\text { the Estimate }\end{array}$ & $\begin{array}{c}\text { R Square } \\
\text { Change }\end{array}$ & F Change & df1 & df2 & $\begin{array}{c}\text { Sig. F } \\
\text { Change }\end{array}$ & $\begin{array}{c}\text { Durbin- } \\
\text { Watson }\end{array}$ \\
\hline 1 & $.657^{\mathrm{a}}$ & .432 & .412 & 3.82271 & .432 & 21.648 & 2 & 57 & .000 & 1.780 \\
\hline
\end{tabular}

a. Predictors: (Constant), Motivasi Belajar, Kompetensi Pedagogik Guru

b. Dependent Variable: Prestasi Belajar

Sumber: data yang diolah dari program SPSS versi 20

Tabel di atas menunjukkan koefisien determinasi $\left(\mathrm{R}^{2}\right)$ yang diperoleh sebesar 0,432 , hal ini berarti 43,2\% prestasi belajar dapat dijelaskan oleh variabel kompetensi pedagogik guru (X1) dan motivasi belajar (X2), Sedangkan 56,8\% lainnya dijelaskan oleh variabel lain yang tidak digunakan dalam penelitian ini. Berdasarkan pada hasil persamaan regresi linier berganda koefisien regresi variabel Kompetensi Pedagogik Guru (X1) menunjukkan bahwa semakin baik kompetensi pedagogik guru maka semakin baik pula prestasi belajar siswa. Koefisien regresi variabel motivasi belajar dalam persamaan regresi menunjukkan perubahan motivasi belajar akan diikuti prestasi belajar pula.

Hasil analisis uji parsial data terbukti bahwa variabel Kompetensi Pedagogik Guru berpengaruh terhadap Prestasi Belajar. Hasil penelitian ini sesuai dengan penelitian yang dilakukan oleh (Umami \& Roesminingsih, 2014), (Inayah, 2013), (Wulandari, 2012). Motivasi Belajar berpengaruh terhadap Prestasi Belajar. Hasil penelitian ini sama dengan penelitian yang dilakukan oleh (Umami \& Roesminingsih, 2014), (Hamdu \& Agustina, 2011), (Narwoto \& Soeharto, 2013), (Paulus Saweduling, 2013).

Berdasarkan pada perhitungan hasil dari uji $\mathrm{F}$ yaitu pengujian secara bersama-sama antara pengaruh variabel Kompetensi Pedagogik guru dan Motivasi Belajar secara simultan berpengaruh terhadap prestasi belajar siswa. Adapun faktor yang mempengaruhi prestasi belajar dalam indikator motivasi belajar yaitu Keterlibatan dan konsentrasi selama mengikuti pembelajaran, Ketekunan merekam tugas terstruktur, Keinginan mendapatkan nilai yang bagus, Tekun dalam menghadapi tugas. Faktor tersebut memiliki pengaruh lebih besar dibandingkan dengan kompetensi pedagogik yang memiliki indikator kemampuan memahami wawasan atau landasan kependidikan, kemampuan memahami peserta didik, kemampuan mengembangkan kurikulum/silabus, kemampuan merancang pembelajaran, kemampuan melaksanakan pembelajaran yang mendidik dan diologis. Berdasarkan hasil analisis tersebut menunjukkan bahwa semakin tinggi motivasi belajar dan Kompetensi Pedagogik Guru maka semakin tinggi juga prestasi belajar siswa.

\section{Kesimpulan}

Kesimpulan yang diperoleh dari hasil penelitian ini antara lain adalah;

1) Terdapat pengaruh antara kompetensi pedagogik guru terhadap prestasi belajar siswa di SMKN 1 Trowulan. Hal ini dibuktikan pada kolom sig pada tabel 0,000 lebih kecil dari 0,05 yang artinya ada pengaruh secara parsial kompetensi pedagogik guru terhadap prestasi belajar siswa.

2) Terdapat pengaruh antara motivasi belajar terhadap prestasi belajar siswa di SMKN 1 Trowulan.Hal ini dibuktikan pada kolom sig pada tabel 0,000 lebih kecil dari 0,05 yang artinya ada pengaruh secara parsial Motivasi belajar terhadap prestasi belajar siswa. 
3) Terdapat pengaruh antara kompetensi pedagogik guru dan motivasi belajar terhadap prestasi belajar siswa di SMKN 1 Trowulan. Hal ini di tunjukkan bahwa nilai $\mathrm{F}$ hitung 21,648 lebih besar dari Ftabel 3,16 yang artinya ada pengaruh secara simultan Kompetensi Pedagogik guru dan Motivasi Belajar terhadap prestasi belajar siswa.

\section{Saran}

Berdasarkan hasil penelitian dan kesimpulan tersebut, maka saran yang dapat peneliti sampaikan adalah sebagai berikut. Guru hendaknya mengembangkan kompetensi pedagogiknya melalui peningkatan kemampuan memahami wawasan atau landasan kependidikan, peningkatan kemampuan memahami peserta didik. Peningkatan kemampuan dalam mengembangakan kurikulum dan silabus, kemampuan dalam merancamg pembelajaran dan kemampuan dalam melaksanakan pembelajaran. Sekolah dapat memfasilitasi guru dalam meningkatkan kemampuan paedagogiknya seperti mengadakan pelatihan-pelatihan, seminar atau workshop. Untuk penelitian selanjutnya hendaknya mampu meneliti faktor-faktor lain yang terkait kemampuan paedagogik guru dengan indikator atau variabel yang lainnya.

\section{Daftar Pustaka}

Afriyani, E., Suklani, S., \& Ridwan, W. A. (2017). Pengaruh Kompetensi Pedagogik Guru terhadap Prestasi Belajar Siswa Madrasah Aliyah (MA) An-Nur Kota Cirebon (Studi pada Pembelajaran Aqidah Akhlak). Al-Tarbawi Al-Haditsah: Jurnal Pendidikan Islam, 2(1), 80-93. https://doi.org/10.24235/tarbawi.v2i1.2029

Andriawati, E. (2013). Pengaruh Kompetensi Pedagogik Guru Terhadap Hasil Belajar Siswa Pada Mata Pelajaran Ekonomi di SMA. Universitas Tanjungpura Pontianak.

Baisa, N.-H., \& Asmahasanah, S. (2020). Pengaruh Kompetensi Pedagogik Guru Terhadap Motivasi Belajar Siswa Di Mi I'Anatusshibyan. Baisa, Asmahasanah, 1(1), 29-41. http://150.107.142.43/index.php/jpg/article/view/2865

Hamdu, G., \& Agustina, L. (2011). Pengaruh Motivasi Belajar Siswa Terhadap Prestasi Belajar IPA di Sekolah Dasar (Studi Kasus terhadap Siswa Kelas IV SDN Tarumanagara Kecamatan Tawang Kota Tasikmalaya). Jurnal Penelitian Pendidikan, 12(1), 81-86.

Inayah, R. (2013). Pengaruh Kompetensi Guru, Motivasi Belajar Siswa, dan fasilitas Belajar Terhadap Prestasi Belajar Mata Pelajaran Ekonomi pada Siswa Kelas XI IPS SMA Negeri 1. Jurnal Pendidikan Insan Mandiri, 1(1), 1-13. http://jurnal.fkip.uns.ac.id/index.php/s2ekonomi/article/view/1899

Narwoto, N., \& Soeharto, S. (2013). Faktor-faktor yang berpengaruh terhadap prestasi belajar teori kejuruan siswa SMK. Jurnal Pendidikan Vokasi, 3(2), 222-233. https://doi.org/10.21831/jpv.v3i2.1603

Ni Made Mega Setyawati, I. K. W. (2020). Pengaruh Kompetensi Pedagogik Guru Dan Disiplin Belajar Siswa Terhadap Prestasi Belajar Siswa Dalam Mata Pelajaran Ekonomi Siswa Kelas XI MIPA SMA Negeri 2 Mengwi Tahun Pelajaran 2019 / 2020. Social StudiesStudies, 8(1).

Novianti, S. D., \& Supardi, E. (2018). Kompetensi pedagogik guru dan motivasi belajar siswa sebagai determinan terhadap hasil belajar siswa. Jurnal Pendidikan Manajemen Perkantoran, 4(1), 107. https://doi.org/10.17509/jpm.v4i1.14961 
Paulus Saweduling. (2013). Motivasi Kerja, Kompensasi, Pelatihan dan Pengembangan, Karakteristik Pekerjaan Terhadap Prestasi Kerja Guru SMP di Kabupaten Kepulauan Talaud. EMBA, 1(4), 582-595.

Prihartanta, W. (2015). Teori-Teori Motivasi. Jurnal Adabiya, Tahun 2015, Vol. 1 No.(83), 1-11. https://www.academia.com

Sulfemi, W. B., \& Lestari, A. H. (2017). Korelasi Kompetensi Pedagogik Guru Dengan Prestasi Belajar Mata Pelajaran IPS di SMP Muhammadiyah Pamijahan Kabupaten Bogor. Jurnal Ilmiah Edutecno, 16(1), 1-17.

Umami, D. R., \& Roesminingsih, E. (2014). Pengaruh Kompetensi Pedagogik dan Motivasi Kerja Guru Terhadap Prestasi Belajar Siswa dalam Ujian Nasional (UN) di SMA Negeri Se Kota Mojokerto. Jurnal Inspirasi Manajemen Pendidikan, 3(3), 81-88.

UU RI. (2005). Undang-Undang RI No. 14 Tahun 2005 Tentang Guru dan Dosen.

Wulandari, D. (2012). Pengaruh Kompetensi Pedagogik dan Kompetensi Profesional Guru terhadap Economic Literacy melalui Prestasi Belajar Siswa Kelas XII IPS di SMA Kota Malang. Jurnal Pendidikan Humaniora, 1(1), 25-29.

Yulianti, F. (2012). Hubungan Kompetensi Pedagogik Guru PAI dengan Prestasi Belajar Pada Mata Pelajaran PAI. Jurnal Tarbawi, 2(2), 109-123. 